\title{
ADJECTIVE BASES FOR DERIVATIVE VERBS WITH INSEPARABLE PREFIXES IN THE GERMAN LANGUAGE
}

\section{Nataliia Derkevych ${ }^{1}$}

DOI: https://doi.org/10.30525/978-9934-26-050-6-55

Words that able to be combined with other words of a certain part of speech in the appropriate grammatical form and to act as a certain member of the sentence, is an external valence [1, p. 18]. The scientist M.D. Stepanova transfers the concept of valence to word formation and introduces the term and concept of internal valence, by which she understands the patterns of lexical content of word-forming models or patterns of combining elements of forming and derivative words at the level of direct components of their lexical basis [4, p. 15].

The concept of internal valence has been used to study word formation mainly on the material of German vocabulary and, as noted by linguists R.V. Yefimov and V.I. Karavashkin, «acquired the character of a theory that defines word-forming phenomena from the standpoint of linguistic potential» [2, p. 1]. The internal valence of language units in word formation is characterized by the fact that: internal valence is manifested in a combination of word-forming components at the level of the word basis to form a derivative basis of a new word; identification of internal valence is possible only through a relative analysis of the derivative basis in terms of its wordforming structure and motivation; internal valence is determined by the potential combination of word-forming components with each other; the concept of internal valence of a word as a potential possibility of combining components of an internal syntagm cannot be applied only to the affixal way of word formation and word composition [4, p. 17].

Internal valence studies two aspects of interaction of the affix and the forming basis: formal and semantic. Formal valence covers the phonetic,

\footnotetext{
${ }^{1}$ Ternopil Volodymyr Hnatiuk National Pedagogical University, Ukraine
} 
morphological, genetic patterns of interaction of the affix with the forming basis. Phonetic regularity is an accentual characteristic of the affix and the forming basis. Morphological regularity determines the compatibility of forming bases of different lexical and grammatical classes of words with each other or with a certain word-forming affix: in our case - regularity of compatibility of verb prefixes with forming bases of different parts of speech verb, noun, adjective, and are determined by the word-forming structure of these verbs. The genetic regularity of combination of affixes and forming bases depends on the origin of direct components of a derivative word.

Semantic cohesion, according to L.G. Levitene, is a necessary condition under which the «hidden» lexical and semantic capabilities of a language unit, which are embedded in its centre to compatibility, can be realized [3, p. 45].

Thus, phonetic, morphological, genetic, semantic regularities of compatibility of components of a derivative word are internal conditions of functioning of a certain word-forming model.

Investigating the structure of a complex word, M.D. Stepanova has developed word-forming models - generalized schematic images of the language structure, according to which occurs the formation of new words in the German language [5, p. 527]. Among these models there is a prefixmodel, which has its own structural and semantic characteristics. The structural feature of a prefix model is the presence of constant components - prefix and lexical basis, which constitute the stability of this model [2, p. 26]. The semantic characteristics of the model are determined by the semantics of the semantic structure of the prefix.

Analyzing adjective derivatives with the prefix be-, it has been found that the prefix forms an internal valence with adjectives of different semantic groups, namely: external and internal signs and human condition: kräftig bekräftigen, lustig - belustigen, selig - beseligen; external signs and condition of an inanimate object: eng - beengen, fest - befestigen, trübe - betrüben; evaluation value: gut - begütigen, schön - beschönigen; color value: grün begrünen, grau - begrauen, dunkel - bedunkeln. In the verbs befeuchten, beengen, benässen, betrocknen, betrüben there is a seme of intensification of the feature of action and coverage of the action by the semantic structure of prefix. Adjectives feucht, frei, naß, reich, which form factitive verbs, are fixed only by the prefix be- - befeuchten, befreien, benässen, bereichern. Seme of ornativity is observed in the verbs begrünen, begünstigen. The prefix be- is also combined with noun-derived adjectives: Kraft - kräftig - bekräftigen, Last - lästig - belästigen, Macht - mächtig - bemächtigen.

Thus, the prefix be- shows the semantic valence to qualitative adjectives, the meaning of which allows to realize in the prefixal verb a seme of intensification of the sign of action, completeness of coverage of action, 
ornativity. Adjectives with zero inflexion and the suffix -ig are selected as the basis for these semantic features.

To form the internal valence of the prefix ent- three semantic groups are selected, which are connected by a common semantic structure of the prefix. A numerous group of adjective derivatives are verbs with a privative meaning: the derivative verb has the opposite meaning to the forming basis: bitter entbittern, dunkel - entdunkeln, kräftig - entkräftigen, menschlich entmenschlichen, mutig - entmutigen, anonym - entanonymisieren. The next group includes factitive verbs that mean the transition to a certain state: entbleichen, entgrimmen, entgrünen. Factitive verbs with the prefix ent- form a third group with the meaning «acquire a certain feature» or «transition to a certain state», which denotes the adjective basis: frei - entfreien, kühn entkühnen, rot - entröten.

Based on the analyzed, we see that the privative seme of the prefix entallows to form with it the factitive adjective-derived verbs, the basis for which are adjectives with zero inflexion and the suffix -isier.

Comparing the semantic connections of the semantic structure of the prefix er- with the semantic structures of adjectives, it has been found that forming bases for the semantics of derivative verbs denote: external and internal features and human condition: grimm - ergrimmen, munter ermuntern; wach - erwachen, this group forms inchoative verbs; adjectives with the meaning of «color and shade» form the factitive derivatives bleich erbleichen, rot - erröten; the prefix er-shows semantic valence on the basis of adjectives formed from abstract nouns and the suffix -ig: Lust - lustig erlustigen; Macht - mächtig - ermächtigen; Mut - mutig - ermutigen. These factitive verbs express the ornativity.

Thus, the prefix er- shows its valence to adjectives that have semantic groups of external and internal features and human condition, «color» with zero inflexion and the suffix -ern and noun-derived adjectives with the suffix -ig.

The prefix ver- reveals valence connections with adjective bases, which denote: external and internal signs and human condition: alt - veralten, blöd verblöden, jung - verjüngen; external features of the subject: breit verbreitern, dick - verdicken, kurz - verkürzern. The prefix ver- is combined with adjectives that denote «colour, a certain shade»: blass - verblassen, dunkel - verdunkeln, grau - vergrauen, grün - vergrünen and denote gradual action. Adjectives of the semantic group of «evaluation» falsch, besser, schlecht, schlimm add to the derivative verbs the seme of intensification of action sign - verfälschen, verbessern, verschlechtern, verschlimmern. The prefix ver- also shows semantic valence to abstract Angst - ängstig verängstigen; Geist - geistig - vergeistigen; Gunst - günstig - vergünstigen and specific noun-derived adjectives Bürger - bürgerlich - verbürgerlichen, 
Körper - körperlich - verkörperlichen, Mensch - menschlich vermenschlichen.

For adjective-derived verbs with the prefix ver- the forming bases are adjectives with seme of external and internal features and human condition, external features of the object, colour, a certain shade, evaluation with zero inflexion, as well as noun-derived adjectives with suffixes -ig, -lich.

The semantic valence of the prefix zer- is limited by its semantic structure: the meaning of distribution, deformation is attached to it, so the adjectives klein, mürbe, weich form verbs with the following semantics: zerkleinern, zermürben, zerweichen.

Therefore, the basis for derivative with the prefix zer- are adjectives with zero morpheme, suffix $-e$ and a higher degree form from klein.

As we can see, the basis for adjective-derived verbs are qualitative adjectives and their grammatical forms. All studied prefixes form adjective derivatives with zero inflexion: be-breit-en, ent-fett-en, er-weich-en, ver-wirren, zer-weich-en. Adjective-derived verbs with inseparable prefixes are also formed in combination with the suffixes -ig - beschönigen, entkräftigen, verfestigen; -ern - belauern, erweitern, verschlimmern, zerkleinern; -lich entmenschlichen, vermenschlichen; -ieren - entanonymisieren, entprivatisieren.

\section{References:}

1. Ghontar T. F. Do problemy valentnosti movnykh odynycj // Movoznavstvo. 1995. № 23. P. 17-21.

2. Efymov R. V., Karavashkyn V. Y. Vnutrennjaja valentnostj slova: teoryja y praktyka: ucheb. posobye. Kharkov, 1977. 87 p.

3. Levytene L. Gh. Voprosы valentnosty y semantycheskogho soghlasovanyja // [sb. nauch. trud.]. M., 1975. P. 43-51.

4. Stepanova M. D. O vneshnej y vnutrennej valentnosty slova // Ynostrannye jazыky v shkole. 1967. № 3. P. 15-16.

5. Stepanova M. D., Zuev A. N., Molchanova Y. D. Slovarj slovoobrazovateljnykh elementov nemeckogho jazyka // Russkyj jazyk. M., 1979. 536 p.

6. Stepanowa M. D., Gerhard Helbig Wortarten und das Problem der Valenz in der deutschen Gegenwartssprache. Leipzig: VEB Bibliographisches Institut, 1978. 215 p. 